\title{
New Tools in Local Energy Planning: Experimenting with Scenarios, Public Participation and Environmental Assessment
}

Jenny Ivner $^{\mathrm{a},{ }^{*}}$, Anna Björklund ${ }^{\mathrm{b}}$ Karl-Henrik Dreborg ${ }^{\mathrm{c}}$, Jessica Johansson ${ }^{\mathrm{c}}$, Per Viklund $^{\mathrm{d}}$, Hans Wiklund ${ }^{\mathrm{d}}$

${ }^{a}$ Linköping University, Linköping Sweden

${ }^{b}$ Royal Institute of Technology, Stockholm, Sweden

${ }^{c}$ Swedish Defence Research Agency, Stockholm, Sweden

${ }^{d}$ Jönköping International Business School, Jönköping, Sweden

*Corresponding author: Environmental Technology and Management, IEI, Linköping University, SE58183 Linköping, Sweden. Email: jenny.ivner@liu.se 


\title{
New Tools in Local Energy Planning: Experimenting with Scenarios, Public Participation and Environmental Assessment
}

\author{
Abstract \\ This article presents a model for local energy planning and applies it in full scale \\ experiment in a Swedish municipality. The model is based on legal requirement, \\ research findings and standards of good practice and includes a combination of \\ analytical and procedural tools intended to support rational decision-making: external \\ scenarios, a citizens' panel, life cycle analysis and qualitative environmental \\ assessment. The application of the model indicates that the decision-support tools \\ selected can give several new and valuable inputs to local energy planning, such as local \\ knowledge and values through citizen dialogue and comprehensive environmental \\ assessments. However, the experiment also shows that there are several challenges \\ involved in applying the tools, for example that it is difficult to get citizens and industry \\ to participate and that it is complicated to combine several different tools for decision- \\ making in one single planning process. Moreover, the experiences from the application \\ suggest that the model for local energy planning show great potential but needs to be \\ improved before it can be used as a standard of good practice.
}

Keywords: Energy planning, decision-making tools, local authority, life cycle assessment (LCA), scenarios, public participation 


\section{Introduction}

The local energy system has a direct effect on municipalities' environmental performance. Local energy planning is an instrument that Swedish municipalities are legally required to use in order to promote energy efficiency, supply, distribution, conversion, and use (SFS 1977:439). Since the European Directive (2001/42/EC) on the assessment of the effects of certain plans and programmes on the environment (European Parliament and the Council 2001) - often referred to as the SEA-Directive, was embodied in Swedish legislation in 2004, energy plans shall also be examined through an environmental assessment (EA). However, recent research results have indicated that energy plans tend to have a systems approach that is narrow and include very sparse EAs and that energy planning could be improved if more actors were involved in the energy planning process (Stenlund 2006; Ivner 2009b).

There is a lack of documented experience of methodology for application of SEA in local energy planning. This has created a need for developing new standards and tools for local energy planning. The purpose of this article is to present a model for local energy planning including a combination of decision-support tools: scenarios, public participation and tools for environmental assessment. The model is tested in full scale experiment in the Swedish municipality Finspång, The model is designed to meet the legal requirements for municipal energy planning but also to apply a number of decision-making tools that in research and standards of good practice are said to improve energy planning. Hence, this model represents a more ambitious approach to energy planning than the minimal requirements stipulated in Swedish legislation.

The aim of this article is to describe this energy planning process and the background to its design and the implementation in a Swedish municipality. This article presents background to, and identified problems with, municipal energy planning in Sweden today and how four well-known decision-making tools may improve these identified shortages. The design and test of an energy planning process based on these tools is then presented and the experiences discussed.

\section{Background}

\section{Municipal energy planning in Sweden}

The Swedish Act on Municipal Energy Planning was established in 1977 and it states that all municipalities should plan for supply, distribution and use of energy within the municipal borders. The act has been revised and completed with additional legislation several times, and the Swedish Energy Agency has provided several handbooks to facilitate local energy planning (Swedish Energy Agency 1998; Swedish Energy Agency 2001b; Swedish Energy Agency 2001a). However, in a national study in 2006, it was concluded that a minority (40\%) of the Swedish municipalities had an energy plan that was less than three years old and one fourth did not have an energy plan at all (Swedish Energy Agency 2006). It was however concluded that most of the local authorities planned to produce an energy plan or update their old plan (ibid). 
Palm (2004) and Olerup (2000) conclude in their studies on Swedish municipalities that municipalities have limited influence over the local energy system, including the municipality-owned energy company. Also, studies performed by Stenlund (2006) indicate that effectiveness of energy planning in terms of fulfilled goals in the studied municipalities was lower when goals or visions in the plans concerned issues owned by private actors. Thus, for energy planning to be a tool that actually leads to change of the local energy systems the energy plan needs to be accepted among a broad range of actors, including industry and the public. That is, the municipal energy plan needs to be legitimate.

Furthermore, Stenlund (2006) also concludes that energy plans have narrow scopes: plans are often technical in their approach, and environmental assessments are very basic or even missing. The focus in many energy plans has been found to be supply and efficiency measures for the service sector. The importance of wide system boundaries and thorough environmental assessments during planning, including energy planning, is highlighted in the SEA-Directive (European Parliament and the Council 2001). The main reason for applying a broad approach EA is to avoid so-called problem shifting, when one measure aimed to solve one problem may lead to other subsequent problems (Wrisberg and de Haes 2002; Raadschelders et al. 2003). A broad approach is also important for energy planning to be relevant and address as many as possible of the issues that are important in the transition towards more sustainable local energy systems.

Against this background, with the identified shortages of municipal energy planning: lack of legitimacy, missing environmental assessments and narrow scopes and the knowledge from a number of research fields, the authors have proposed and tested an energy planning process. The process is based on SEA-procedures and four decisionmaking tools described below and make a full scale experiment of the application and integration in a real case.

\section{Tools that may improve local energy planning}

The process designed is based on an SEA framework as described in the EC directive (2001/42/EC). The objective of an SEA is to identify the likely significant effects on the environment of implementing a plan. According to the adaption of the EC directive (2001/42/EC) into Swedish legislation, the EA should also present a similar assessment of reasonable alternatives, the current state of the environment, and of the likely evolution thereof without implementing the plan - a no-action alternative (SFS 1998:808). Another important part of the EA is public participation. An increased public involvement in political decisions, it is argued, could revitalize democracy and create improved political decision.

There are a vast number of methods and tools that can be used in SEA procedures (Petts 1999; Tyldesley 2003; Thérivel 2004). Some of these have been identified as especially suitable for the energy sector (Finnveden et al. 2003). The choice on which tools to use depends on the available resources, such as data or personnel, and on the type of information that is needed to be able to sufficiently assess the environmental consequences. . In this case, four decision-making tools that have been identified as suitable for SEA were chosen for different parts of the proposed energy planning 
process: a citizens' panel for public participation and improved legitimacy, two scenario approaches for alternative generation to support a broad approach, and indicators and life cycle assessment (LCA) for qualitative and quantitative EAs.

\section{Public participation for legitimacy}

Public participation is claimed to further legitimacy and rationality in collective decision-making through involving citizens and facilitating exchange of information and arguments (Dryzek 1990; Benhabib 1996; Gutmann and Thomson 2004).

Participatory planning is considered to improve planning in terms of acceptance and ability to generate public support, at the same time as it promotes social justice and environmental sustainability (Healey 1993). Also energy planning literature stress the importance, since acceptance and action from private actors is important when implementing the plans (Jank 2000; Ling et al. 2002; Rydén 2006). However, public participation in municipal planning has long been a challenge (Khakee 1999). One important question is how this participation could be designed and institutionalised (Viklund 1996; Smith and Wales 2000). There are many forms of public participation (Gilljam et al. 2003). Empirical research suggests that "good participatory practice" is characterised by that all stakeholders are included, information is shared openly and readily, participants find the interactions meaningful, and that there is a will to find solutions of mutual interest (Webler and Tuler 2006).

A current trend in democratic theory and planning theory is designing deliberative ${ }^{1}$ tools (Wiklund 2005). The common denominator for many deliberative tools is the focus on enabling rational argumentation and dialogue between experts and ordinary citizens, for example during in planning activities. EA itself has in fact been described as a deliberative tool with the potential to improve environmental decision-making (Palerm 2000; Sager 2001; Petts 2003; Wilkins 2003; Bond et al. 2004). As Petts (2003) puts it: "EIA (including SEA) has the potential to be a decision process that includes deliberation, inherent learning and decision influence through stakeholder and public input." But deliberative democratic and participatory planning ideals have also been criticised for being unrealistic. It has been claimed that citizens do not have the necessary knowledge for participation and that undistorted dialogue cannot be achieved due to various resource-related barriers to participation (Wiklund 2005).

Public participation was in this energy planning process ensured by a citizens' panel (inspired by the concept of Citizens' Jury, described in for example Crosby (1999)) that took part in a series of workshops. The aim with the panel was to involve more actors in the early stages of the energy planning process and hence add legitimacy to the energy plan. The intention was to enhance possibilities to achieving goals involving private actors.

\section{Scenario techniques for a broader perspective}

Scenarios are defined here as a narrative of a future state including a description of the principal driving forces involved in the transition from the present to the future. Scenarios can be produced in several ways and the approach applied in this energy

\footnotetext{
${ }^{1}$ Deliberation $=$ a discussion and consideration by a group of persons of the reasons for and against a measure (Encyclopedia Brittanica)
} 
planning process is a combination of two different traditions. The first is backcasting as described by Robinson $(1982 ; 1990 ; 2003)$, Dreborg $(1996 ; 2004)$ and Höjer and Mattsson (2003). This approach is used in normative planning; images of a desired future are developed and a possible policy path leading from the present to the visionary future state is sought. Backcasting has been applied to the problem of sustainability in local and regional planning (Carlsson-Kanyama et al. 2008). The possibilities to improve backcasting processes with stakeholder participation has been emphasised by for example Robinson (2003), Quist and Vergragt (2006), and Carlsson-Kanyama et al. (2008).

The second tradition is scenario planning using external scenarios as outlined by e.g. Wack (1985b; 1985a), Schwartz (1992), van der Heijden (2005), Dreborg (2004) and Eriksson (2004a). External scenarios describe the development of important factors outside the control of the planning entity that affect the range of possible actions. Different planning alternatives are assessed against the scenarios in order to find a combination of actions that are favourable under as many external developments as possible. Use of workshops with structured brainstorming is common in processes to develop external scenarios; it is considered essential that a wide range of stake-holders and experts take part in these workshops. Scenario planning is considered to increase the chances of reaching planning goals by addressing a broader scope of challenges than is usual in planning without scenarios.

These two scenario techniques were applied in this energy planning process with the aim to broaden the scope of goals to include not only technical energy systems but also life-style issues and to find robust alternatives to reach these goals. The two scenario techniques were used in three workshops. Images of a desired future and external scenarios were developed during two different workshops ${ }^{2}$. Alternatives that that could lead to the desired future, within each external scenario, were sought in the last workshop.

\section{Quantitative and qualitative approaches to environmental assessment}

The main purpose of SEA is to facilitate early and systematic consideration of potential environmental impacts of alternative courses of action.

Literature suggests that there is a need to combine qualitative and quantitative tools for the EA. It is argued in literature on decision-making tools that complex decision making could benefit by using a combination of different tools (English et al. 1999; Wrisberg and de Haes 2002). Pietrapertosa et al. (2009) and Hochschorner and Finnveden (2003) have shown that advantages arise from combining different tools since it allows the user to take advantage of the strengths of each approach. Also Hobbs and Horn (1997) are in favour of using multiple methods with arguments such as, "increased validity of results lead to better confidence in the quality of the decisions."

The quantitative tool used was Life Cycle Assessment (LCA), a tool to assess the environmental impacts and resources used throughout a product's life cycle, "from cradle to grave" - from production, through use to disposal (ISO 2006a; ISO 2006b). A

\footnotetext{
${ }^{2}$ By future image we mean a snap shot of a future state
} 
product in this sense is not necessarily a physical item, but may also be a service. LCA has been highlighted as a suitable tool for environmental assessment in the energy sector because it offers comprehensive environmental assessment and a life cycle perspective (Finnveden et al. 2003).

In this energy planning process, EAs were made for the alternative actions or measures proposed by the citizens' panel to be included in the energy plan. LCA was used to assess the life cycle impacts of for instance energy supply and use. A qualitative approach using a checklist with environmental indicators was applied to the alternatives that were not possible or meaningful to analyse using LCA, for example information projects.

\section{Combination of scenarios and EA for robust strategies}

The combination of quantitative EA and external scenarios was used with the aim to identify robust and adaptive strategies that could lead to the desired future energy system. Robust strategies are those that are favourable in a wide range of future scenarios. Using adaptive strategies mean that an early technological lock-in can be avoided through sequential decision-making. This can be useful in the face of uncertainty that resolve over time (Eriksson 2004a; Eriksson and Weber 2008). Striving for robust and adaptive strategies is therefore a way to be better prepared for an uncertain future (Finnveden et al. 2005). The search for robust strategies can be considered as an attempt to broaden perspectives in planning processes, where suggested actions and measures are assessed towards a wide range of possible developments.

\section{Test of the energy planning process in Finspång municipality}

The energy planning process that was tested in Finspång was based on the assumption that local energy planning can be improved using the decision-making tools described above. The process includes a number of steps, table 1 . The steps were inspired the phases of an EA described in the SEA directive, and a number of handbooks for local energy planning (California Energy Commission 1997; Swedish Energy Agency 1998; Jank 2000; Joanneum Research 2000; Johansson 2001; Swedish Energy Agency 2001b; Swedish Energy Agency 2001a)

[Table 1]

As mentioned earlier in this article, the development and implementation of the energy planning process is a full scale test in a Swedish municipality, Finspång. The process took more than three years and therefore included not only the challenges of integrating different decision-making tools in a joint process, but also the challenges to apply tools at the local level in a real-time planning process.

\section{Finspång municipality}

Finspång municipality with its 21,000 inhabitants is situated in south-eastern Sweden. The landscape is dominated by forests, and most people live in the town of Finspång (and suburb thereof) and a couple of larger villages. Nearly $50 \%$ of the employment is 
within the industrial sector. The cooperation with the research group was initialized as a civil servant took contact for advice on how to proceed with the energy planning process. The research group found Finspång suitable for the research project described here. Several factors added to this suitability: the timeliness of the planning commencement; the relatively small size of municipality, which means that developed methods may be useful for many other municipalities; planned district heating expansion, several energy-intensive industries, large transportation needs; and also the open attitude from the local authority.

\section{Implementation of process}

The following section describes how the proposed energy planning process was tested in Finspång municipality, step by step. The energy planning process also included steps for compilation of the energy plan, remittance, and adoption, which are the responsibility of the municipal work group. However, these last steps were not finalised at the time this article was written. Therefore, this description includes only the steps in the energy planning process that include the tested decision-making tools and activities by the research group.

\section{Step 0 - Start of process}

The first step included initial meetings where a working group consisting of civil servants from several departments in the municipality was formed, including the municipally owned energy company. The intention was that this work group should be the leading actor through the energy planning process, which proved hard to achieve since the process was designed by the research group. Most of the administration and management of the process were therefore made in cooperation between the municipal work group and the research team.

Timeframe, objectives and course of the process were also discussed and defined at this step. The process was then presented for acceptance by the local government and it was decided that contacts with politicians should be informal to make the process run smoother.

\section{Step 1 - Collection of background information}

During this step, the status of the current energy system was documented in terms of available energy sources, conversion plants and annual energy use in different sectors. The environmental pressure from the local energy system was analysed (Eriksson 2004b). Furthermore, general information about the municipality such as demographic data, industry structure and development plans in various sectors of the municipality was gathered at this stage. This information was used in the development of the noaction alternatives in the EA of proposed strategies and actions (Step 7).

\section{Appointment of citizens' panel}

During the start of the process, the research group conducted interviews with local business and industry about their views on energy and sustainability issues. These companies were also invited to take part in the energy planning process. The research group and the municipal work group also agreed that an invitation to the citizens' panel should be announced in the local newspaper. Additionally, the civil servants were encouraged to contact their own networks and non-profit organisations in search for 
potential participants. The response from the newspaper announcement was sparse, so most of the participants in the panel were recruited from the civil servants' personal networks and non-profit organisations. One participant in the panel was from a local housing company. The citizens' panel consisted originally of a dozen participants, of which nine participated on a regular basis. From the start it was clarified that the citizens' panel would not to have any decisive power on the final energy plan, but rather a kind of recommending power as an input for further developing stages.

\section{Steps 2-5 - Scenario analysis and formulation of alternatives}

As mentioned above, the tested energy planning process combines public participation through a citizens' panel with scenario methodologies. A group consisting of the citizens' panel, the municipal work group, and some experts (external as well as from the research group) participated in three scenario workshops. The workshops had the objective to contribute to the formulation of municipal strategies for energy supply, distribution and use.

\section{Step 2-Workshop: "Development of a visionary image of the future"}

The aim of the first workshop was to develop a visionary image of the future Finspång. A structured brainstorming event was held around the focus question: "How do we live and work in Finspång in the year 2040 so that the energy use is ecologically, socially and economically sustainable?" Each participant was allowed to present their ideas one at the time without being interrupted or questioned and the ideas were written on postits and placed on a wall. When the panel ran out of ideas, the post-its were grouped and participants living or working in Finspång were encouraged to vote on the proposals they found most and least attractive. This methodology is based on techniques developed by Royal/Dutch Shell (van der Heiden 1996). Similar techniques are described in (Schnelle 1979; Eden and Ackerman 1998).

This first workshop was considered successful: the citizens were active and the outcome was concrete (Ivner 2009a). How much the visionary image of the future image actually affected the final energy plan is however uncertain, see step 4.

\section{Step 3 - Visionary image}

A draft image of a desirable future based on the most popular ideas was composed by the research group after the first workshop. This image was presented to the citizens' panel at the second workshop (Step 4). The aim was to concretize what a future sustainable energy system could look like and to create a common understanding of what magnitude of change that may be needed to accomplish the desired future. The image was then revised to reflect the participants' comments. As it was decided in step 0 that contacts with politicians should be informal, there was no political decision about the vision for the future energy system. The municipal workgroup considered this as a wise choice, since the process still took a long time to implement. If there should have been long periods of time waiting for political decisions, this process would have been even more prolonged (Ivner 2009a).

\section{Step 4-Workshop: "Development of external scenarios"}

The second workshop started with discussions on a draft visionary image prepared by the research group. Most of the participants were satisfied with the draft and thought 
that it had captured the important features of the discussions in the previous workshop. Some minor changes to the draft scenario were agreed after a discussion about whether the visionary image was too idealistic.

After this discussion the citizens' were asked to brainstorm around the focus question: 'What outside factors affect the possibilities of Finspång to achieve an ecologically, socially and economically sustainable energy system?' The time horizon was 15 to 20 years from the present. The participants were first asked to vote on the ideas they found most the important. In a second round, they voted on which of the most important factors they thought were most uncertain. Four scenarios, based on the most important and most uncertain factors, were then created by the research group. The scenarios were initially qualitative, but later some aspects were quantified in order to serve as a basis for the quantitative EA.

\section{Step 5 - Workshop: "Suggestions of actions and strategies"}

The aim of the third workshop was to generate proposals for measures and strategies to be included in the energy plan. The panel was split into four groups, one for each scenario. They were assigned to generate ideas on actions and strategies to reach the desired future image, suitable for their scenario. However, much attention during this workshop was paid to the external scenarios: several participants found the methodology complicated and it also occurred that citizens did not want to work within a scenario they did not believe in or found undesirable (Ivner 2009a). Therefore it is not certain how much the future image from step 2 actually influenced the suggestions from the panel.

\section{Step 6 - Selection of actions and strategies}

In this step the municipal workgroup made a selection from actions and strategies from Step 5, judging whether they seemed at all possible to act upon. After this selection there was a list of 60 actions and strategies that were subject for EA.

\section{Step 7 - Environmental assessment}

In the EA, the list of actions and strategies from Step 6 were evaluated. Ten of the suggested actions were assessed quantitatively, the rest (50) were assessed with aid of the qualitative checklist since they were not possible or meaningful to analyse with LCA. In the quantitative EA, the potential impacts of each of the ten actions were evaluated in each external scenario. The energy balance for Finspång, issued by Statistics Sweden (2003), was used as template for the modelling of energy supply and use. The energy balance describes energy supply and use, and was used to develop an LCA model that calculates energy related life cycle emissions and resource use in the municipality. The LCA procedure is further described and discussed in Björklund (2008; Manuscript)

The qualitative EA was made in collaboration by researchers and the municipal work group. It was based on a description of how different energy carriers affect the environment, provided by the research group, and a checklist with a number of environmental indicators. The indicators were based on the regional implementation of the Swedish national environmental objectives and indicators established by the 
Swedish EPA, and impact categories deemed as being important by the Swedish Energy Agency (Swedish Energy Agency 2002b; Swedish Energy Agency 2002a),

One methodological challenge concerned the combination of the mainly qualitatively described external scenarios and proposed actions with quantitative LCA. Scenarios and actions needed to be interpreted in quantitative terms. These interpretations were discussed among the researchers and the municipal workgroup. One subject for discussion was the actual responsibility of the municipality. LCA is designed to assessed environmental impacts on a global scale, but the jurisdiction of the local authority is limited to the municipal territory (Björklund 2008; Björklund Manuscript).

The qualitative assessment of the long list of suggested actions from step 5 was the main responsibility of the municipal workgroup. The civil servants found this hard and complicated, despite the initial support and pre-defined methodology provided by the researchers. One reason for this is that the researchers from the start offered support for the EAs, which from the researchers' point of view meant the use of LCA. But as the process proceeded and it became obvious that only a small part of the suggested actions could be assessed quantitatively the focus, and the responsibilities, for the EAs shifted.

\section{Step 8 - Valuation and choice of robust strategies}

Based on the results of the EAs from Step 7, the research group and municipal work group together analysed whether actions and strategies are robust in terms of environmental improvement. An actionthat showed a positive environmental effect in all scenarios was regarded as robust and was chosen as a strong candidate to the energy plan. An action that showed a negative effect in at least one scenario was investigated further - if it was flexible, i.e. could be changed or replaced by another action at short notice and without large costs, it could be included in the plan without risk. If the action meant a long term binding investment, for example construction of a combined heat and power plant, this would entail a risk. Such a measure would lock-in the local energy system to a structure that might prove (environmentally) outdated under some plausible future conditions. In such cases, which were rare, the research group and the civil servants tried to find ways to improve the measure by making it more flexible and robust.

The civil servants felt that the outcome of the EAs and evaluation of robustness did not meet their expectations. One reason was that only ten out of 60 actions were possible to assess quantitatively. Another reason was that several actions that were expected to be good from environmental point of view did not show good results in the external scenarios (Ivner 2009a). This was because all scenarios ended up mirroring positive developments. The reason for this was that a high oil price was considered as a certain and important factor in workshop 2, which in turn lead to a large share of renewable energy in the energy system in all four scenarios. This also lead to that the four external scenarios were generally quite similar, see Björklund (2008; Manuscript).

\section{Step 9 - Feedback to the citizens' panel}

Evaluations and chosen actions were presented to the panel. All in all, the panel was satisfied with the outcome after the workshops. Some of the actions that had been 
abandoned in earlier steps were however re-introduced. This is an example of the iterative nature of a SEA-process.

\section{Step 10 - Development of implementation part in energy plan}

Specific goals and actions for the energy plan based on the strategies that were considered robust and flexible in Step 9 were composed by the civil servants in this step. Also actions and routines for implementation were specified together with a number of check-points for future evaluation of the real development and its compliance with the plan.

\section{Compilation, remittance and adoption}

The energy plan including background information, goals and actions, and EA results has been be compiled by the civil servants and sent for remittance within Finspång municipality. A large number of comments to the energy plan have been received and several discussion about the local energy system have been initiated: from the use of waste heat from industry to lobbying for infrastructure for biogas vehicles. Discussions that representatives from the municipality mean are direct spin-offs from the attention given to the unique energy planning process. After the revision, the final municipal energy plan will be considered for adoption by the local government.

\section{Experiences from the process}

The following section presents an analytical discussion about the implementation of the energy planning process and the application of the decision-making tools. Special attention is paid to whether the tools had the intended effects; to give legitimacy, to support a broad approach and to include comprehensive EAs.

\section{Citizens' panel and participation}

Although the citizens' panel was not representative from a statistical point of view, the panels' mix of age, gender and occupation created a diverse group of people, a panel of many voices. From the citizen's panel's point of view the dialogue as such was considered unconstrained, interesting and productive. Some of them were even surprised that such a small and diverse group of people could generate that many and challenging suggestions for a future environmental sustainability. Survey data also shows that proposed environmental measures of the citizens' panel had strong support from the citizens of the local community (Wiklund and Viklund 2006). However, to increase the legitimacy of the planning process the recruitment to the citizen panel should be more inclusive and random.

The problem of scale and limited resources is of course of great importance in deliberative democracy. The deliberative democratic ideal is impossible to fulfil in its purest sense (Benhabib 1996; Goodin 2000; Parkinson 2003). In an ideal situation legitimacy comes from "the free and unconstrained deliberation of all about matters of common concern" (Benhabib 1996). In real life settings there are always barriers to participation. Participatory tools can not be perfectly inclusive, not everyone concerned could in real life be included. Many of them that are affected by a decision do not have the financial resources or the knowledge to for effective participation. Viewed from a more pragmatic point of view, the goal is therefore to find participatory tools that 
enhance dialogue and learning even though there are barriers to inclusion and effective participation. The citizen panel is an attempt to find a robust deliberative tool that can be used in real planning. It is a time efficient and relatively inexpensive way of involving the public and it makes it possible to discuss complicated matters and build trust.

With available resources taken into account, we suggest that the panel could be expanded somewhat in numbers and also include other stakeholders, especially from the local trade and industry sector. John Parkinson (2003) has suggested that the group of citizens in a deliberative democratic setting should be less than 20 persons, otherwise deliberative conversation and reason will be replaced by speech-making and rhetorical appeals. A possible solution to the problem of scale, perhaps better described as the problem of deliberative economy, is also a recruiting procedure to select representative participants by lot. This proposal is presented by John Dryzek (2001), together with the argument that compared to other solutions to the problem of scale it has the fewest problems for democratic legitimacy.

\section{The application of scenarios and EAs}

The work with the visionary image of the future was considered positive since it allowed the municipal workgroup to get together with citizens and experts to discuss different conceptions of what a future sustainable local energy system may look like. A more logical and coherent process would perhaps been obtained if goals for the energy process inspired by the future image would have been more clearly stated in a following phase.

As part of a learning process it was probably useful to become aware of how different external factors may influence the local energy system in the future. The external scenarios developed did however not become as useful as expected. It was difficult for the participants to connect to the scenarios and to design actions to suit them. The impression is that the participants mostly had their preferred actions and strategies that they would have proposed regardless of the scenarios. But nevertheless some of the more radical actions that were entered in the draft energy plan were clearly products of the scenario workshops and would probably not have appeared if a more ordinary planning process had been followed (Ivner 2009b).

The external scenarios were also intended to work as a test bed for proposed actions to aid the search for environmentally robust strategies. The way the scenarios were quantified as a basis for the LCA calculations however resulted in that they were quite similar, so that the differences between actions in the different scenarios were small. The robustness analysis would probably have been more valuable had it been made with a broader scope considering more aspects than just environmental performance and if it had been made for all the proposed actions, based on qualitative or semi-qualitative reasoning, starting from the present up until the time horizon of the scenarios. Such an approach may have lead to more of the suggested advantages of combining decisionmaking tools as implied by earlier research (English 1999; Wrisberg and de Haes 2002; Hochschorner and Finnveden 2003; Pietrapertosa et al. 2009). Another option is to omit 
external scenarios and focus more on other scenario techniques or visionary future images.

\section{Concluding discussion}

This article has its starting-point in some earlier identified problems and shortages in current energy planning practice. Its aim is to present an energy planning process designed to address these shortages, describe its implementation in a full-scale real planning process together with a workgroup in a Swedish municipality, and discuss experiences from this implementation.

The first conclusion is that this experiment was possible to complete, even though some modifications were made during the course of the process. This process has shown that several advantages can be achieved by applying decision-making tools in local energy planning, for example new ways of meeting citizens, attention to energy issues in the municipality and more comprehensive environmental assessments. In fact, even though only a small part of the background material from the EAs was presented in the draft energy plan, the EAs presented were much more comprehensive than in other recently adopted Swedish municipal energy plans (Ivner 2009b).

There were also several challenges faced during this process, for example the difficulty to attract citizens to the panel, the relative complexity in the application of external scenarios and difficulties to use quantitative EAs in a qualitative setting of prerequisites and suggested actions. It should be noted that the chosen decision-making tools were only an example of tools that may be applied in local energy planning. Other tools may be as useful and feasible to use as these

The results from this experiment imply that there is a need to simplify the methods used in order to make them feasible to use in local energy planning. For example, as the EAs in the Finspång energy plan was more comprehensive than in other recently adopted Swedish energy plans this suggests that also simplified EAs can provide useful information. Also the satisfaction of the discussions with the citizens' panel among the municipal workgroup and that actions suggested by the panel was supported by the public implies that even though the panel was not entirely representative for all stakeholders they contributed to the energy planning process.

To conclude, this experiment has shown that there is large potential in applying a combination of decision-making tools in local energy planning, but that there are still methodological at practical challenges that need to be dealt with. It also suggests that simplified solutions for the application of tools can contribute substantially to local energy planning processes.

\section{Acknowledgements}

This article was produced as a result from two different research projects within the research programme MiSt, funded by the Swedish Environmental Protection Agency and a research project funded by the Swedish research council FORMAS. The authors would like to thank the municipal workgroup in Finspång, and especially Per Strannelid, for their positive attitude and commitment. 


\section{References}

Benhabib, S. (1996). Toward a Deliberative Model of Democratic Legitimacy In:

S. Benhabib, ed. Democracy and Difference. Contesting the Boundaries of the Political. Princeton: Princeton University Press, 67-94.

Björklund, A. (2008). Livscykelanalys Av Åtgärder För Minskad

Energianvändning i Finspång. Rapport från ett Projekt om metoder för

Strategisk Miljöbedömning i Energiplanering. Stockholm: Royal Institute of

Technology.

Björklund, A. (Manuscript). Life Cycle Assessment as an Analytical Tool in Strategic Environmental Assessment. Case Study on Local Energy Planning.

Bond, A., J. Palerm and P. Haigh (2004). Public Participation in Eia of Nuclear Power Plant Decomissioning Projects: A Case Study Analysis. Environmental Impact Assessment Review, 24(6), 617-641.

California Energy Commission (1997). Energy Aware Planning Guide:

California Energy Commission.

Carlsson-Kanyama, A., K. H. Dreborg, H. C. Moll and D. Padovan (2008).

Participative Backcasting: A Tool for Involving Stakeholders in Local

Sustainability Planning. Futures, 40(1), 34-46.

Crosby, N. (1999). Using the Citizens' Jury(R) Process for Environmental Decision Making In: K. Sexton, A. A. Marcus, K. W. Easter and T. D.

Burkhardt, ed. Better Environmental Decisions. Washington, D.C: Island Press, 456.

Dreborg, K. H. (1996). Essence of Backcasting. Futures, 28(9), 813-828.

Dreborg, K. H. (2004). Scenarios and Structural Uncertainty: Exploration in the Field of Sustainable Transport. Thesis (PhD). Royal Institute of Technology, Stockholm.

Dryzek, J. S. (1990). Discursive Democracy. Politics, Policy and Political Science. Cambridge: Cambridge University Press.

Dryzek, J. S. (2001). Legitimacy and Economy in Deliberative Democracy Political Theory, 29(5), 651-669.

Eden, C. and F. Ackerman (1998). Making Strategy: The Journey of Strategic Management. London: Sage Publications. 
English, M. R. (1999). Environmental Decision Making by Organizations:

Choosing the Right Tools In: K. Sexton, A. A. Marcus, K. W. Easter and T. D. Burkhardt, eds. Better Environmental Decisions. Washington, D.C: Island Press, $57-75$.

English, M. R., V. H. Dale, C. V. Riper-Geibig and W. H. Ramsey (1999). Overview In: V. H. Dale and M. R. English, eds. Tools to Aid Environmental Decision Making. New York: Springer, 1-31.

Eriksson, E. A. (2004a). Scenario-Based Methodologies for Strategy

Development and Management of Change In: M.-O. Olsson and G. Sjöstedt, eds. Systems Approaches and Their Application: Examples from Sweden. Dordrecht: Kluwer Academic Publishers, 167-194.

Eriksson, E. A. and M. K. Weber (2008). Adaptive Foresight: Navigating the Complex Landscape of Policy Strategies. Technological Forecasting and Social Change., 75(4), 462-482.

Eriksson, O. (2004b). Analys av ett Lokalt Energisystem och Dess Miljöpåverkan -Nulägesbeskrivning av Finspångs Energisystem. Thesis (Master). Linköping University.

European Parliament and the Council (2001). Directive 2001/42/Ec of the European Parliament and of the Council of 27 June 2001 on the Assessment of the Effects of Certain Plans and Programmes on the Environment. Official Journal of the European Communities, L197(21/07/2001), 0030 - 0037.

Finnveden, G., A. Björklund, M. Carlsson Reich, O. Eriksson and A. Sörbom (2005). Robusta Och Flexibla Strategier För Utnyttjande Av Energi Ur Avfall. Stockholm: Royal Institute for Technology.

Finnveden, G., M. Nilsson, J. Johansson, Å. Persson, А̊. Moberg and T. Carlsson (2003). Strategic Environmental Assessment Methodologies - Applications within the Energy Sector. Environmental Impact Assessment Review, 23(1), 91123.

Gilljam, M., O. Jodal and O. Cliffordson (2003). Demokratiutveckling I Svenska Kommuner. Del 1. En Kartläggning Över Vad Som Gjorts. Gothenburg: CEFOS, Gothenburg University.

Goodin, R. E. (2000). Democratic Deliberation Within. Philosophy \& Public Affairs, 29(1), 81-109. 
Gutmann, A. and D. Thomson (2004). Why Deliberative Democracy. Princeton: Princeton University Press.

Healey, P. (1993). Planning through Debate: The Communicative Turn in Planning Theory In: F. Fischer and J. Forester, ed. The Argumentive Turn in Policy Analysis and Planning. London: Duke University Press.

Hobbs, B. F. and G. T. F. Horn (1997). Building Public Confidence in Energy Planning: A Multimethod Mcdm Approach to Demand-Side Planning at Bc Gas. Energy Policy, 25(3), 357-375.

Hochschnorner, E. and G. Finnveden (2003). Evaluation of Two Simplified Life Cycle Assessment Methods. International Journal of Life Cycle Assessment, 8(3), 119-128.

Hochschorner, E. and G. Finnveden (2003). Evaluation of Two Simplified Life Cycle Assessment Methods. International Journal of Life Cycle Assessment, 8(3), 119-128.

Höjer, M. and L.-G. Mattson (2003). Determinism and Backcasting in Future Studies. Futures, 32(7), 613-634.

ISO (2006a). Environmental Management - Life Cycle Assessment - Principles and Framework.

ISO (2006b). Environmental Management - Life Cycle Assessment Requirements and Guidelines.

Ivner, J. (2009a). Energy Planning with Decision-Making Tools:Experiences from an Energy-Planning Project. Local Environment, 14(9), 833-850.

Ivner, J. (2009b). Muncipal Energy Planning: Scope and Method Development. Thesis (PhD). Linköping University.

Jank, R., Ed. (2000). Advanced Local Energy Planning (Alep) - a Guidebook, International Energy Agency.

Joanneum Research (2000) Handbuch Für Kommunale Und Regionale Energieplanung. [Online]. Available from: http://server3.store.co.at/joanneum/basis/index.htm [Accessed 16 August 2003]

Johansson, B. (2001). Effektiv Energiplanering För Ett Hållbart Samhälle. Stockholm: Forskningsrådet för miljö, areella näringar och samhällsbyggande, Formas. 
Khakee, A. (1999). Demokrati I Samhällsplaneringen In: E. Amnå, ed. Sou 199:113, Medborgarnas Erfarenheter: Forskarvolym V. Stockholm: Statens offentliga utredningar.

Ling, E., K. Mårtensson and K. Westerberg (2002). Mot Ett Hållbart Energisystem. Fyra Förändringsmodeller. Malmö: Malmö Högskola.

Olerup, B. (2000). Scale and Scope in Municipal Energy Planning in Sweden. Journal of Environmental Planning \& Management, 43(2), 205-221.

Palerm, J. (2000). An Empirical-Theroretical Analysis Framework for Public Participation in Environmental Impact Assessment. Journal of Environmental Assessment Policy and Management, 45(5), 581-600.

Palm, J. (2004). Makten Över Energin - Policyprocesser i Två Kommuner 19772001. Thesis $(\mathrm{PhD})$. Linköping university.

Parkinson, J. (2003). Legitimacy Problems in Deliberative Democracy. Political Studies, 51(1), 180-196.

Petts, J., Ed. (1999). Handbook of Environmental Impact Assessment. Vol.1 and 2. Oxford, Blackwell Publishing.

Petts, J. (2003). Barriers to Participative Deliberation in EIA: Learning from Waste Policies, Plans and Projects. Journal of Environmental Assessment Policy and Management, 5(3), 296-293.

Pietrapertosa, F., C. Cosmi, M. Macchiato, M. Salvia and V. Cuomo (2009). Life Cycle Assessment, Externe and Comprehensive Analysis for an Integrated Evaluation of the Environmental Impact of Anthropogenic Activities. Renewable and Sustainable Energy Reviews, 13(5), 1039-1048.

Quist, J. and P. Vergragt (2006). Past and Future Backcasting: The Shift to Stakeholder Participation and Proposal for a Methodological Framework. Futures, 38(9), 1027-1045.

Raadschelders, E., J.-P. Hettelingh, E. van der Voet and H. A. Udo de Haes (2003). Side Effects of Categorized Environmental Measures and Their Implications for Impact Analysis. Environmental Science \& Policy, 6(2), 167174.

Robinson, J. (1982). Energy Backcasting: A Proposed Method of Policy Analysis. Energy Policy, 10(4), 337-344. 
Robinson, J. (1990). Futures under Glass: A Recipe for People Who Hate to Predict. Futures, 22(8), 820-842.

Robinson, J. (2003). Future Subjunctive: Backcasting as Social Learning. Futures, 35(8), 839-856.

Rydén, B. (2006). Energy Planning as Part of Public Planning In: B. Johansson, B. Olofsdotter, C. Rolén and B. Sellber, eds. Energy and the Built Environment in Sweden. Västerås: Formas.

Sager, T. (2001). A Planning Theory Perspective on Eia In: T. Hilding-Rydevik, ed. Eia, Large Development Projects and Decision-Making in the Nordic Countries. Stockholm: Nordregio, 197-218.

Schnelle, E. (1979). The Meta-Plan Method: Communication Tools for Planning and Learning Groups. Hamburg: Quickborn.

Schwartz, P. (1992). The Art of Long View. London: Century business.

SFS 1977:439 (1977). Lag Om Kommunal Energiplanering. Stockholm: Riksdagstryck.

SFS 1998:808 (1998). Lag (1998:808), Miljöbalk. Stockholm: Riksdagstryck.

Smith, G. and C. Wales (2000). Citizens' Juries and Deliberative Democracy. Political Studies, 48(1), 51-65.

Statistics Sweden (2003). Kommunala Energibalanser. Electronic source: Statistiska Centralbyrån.

Stenlund, J. (2006). Plan and Reality - Municipal Energy Plans and Development of Local Energy Systems. Thesis (Licentiate). Linköping Universtity.

Swedish Energy Agency (1998). Miljöanpassade Lokala Energiplaner Exempel. Stockholm: Swedish Energy Agency.

Swedish Energy Agency (2001a). En Hållbar Lokal Energistrategi, Milen 2000. Stockholm: Energimyndigheten and Naturvårdsverket.

Swedish Energy Agency (2001b). Milen Inspiration: Internationell Lokal Energiplanering. Stockholm: Statens energimyndighet. 
Swedish Energy Agency (2002a). Energiindikatorer 2002 För Uppföljning Av Sveriges Energipolitiska Mål. Stockholm: Statens energimyndighet.

Swedish Energy Agency (2002b). Guide Till Indikatordjungeln: Indikatorer Inom Energiområdet. Stockholm: Statens energimyndighet.

Swedish Energy Agency (2006). Kommunal Energiplanerging - En Enkätundersökning Av Sveriges Kommuner. Eskilstuna: Statens Energimyndighet.

Thérivel, R. (2004). Strategic Environmental Assessment in Action. London: Earthscan.

Tyldesley, D. (2003). Environmental Assessment of Development Plans. Edinburgh: Scottish Executive Social Research.

Wack, P. (1985a). Scenarios, Shooting the Rapids. Harward business review, 131-142.

Wack, P. (1985b). Scenarios, Uncharted Waters Ahead. Harward business review, 79-90.

van der Heiden, K. (1996). Scenarios: The Art of Strategic Conversation. Chichester: John Wiley \& Sons.

van der Heiden, K. (2005). Scenarios: The Art of Strategic Conversation. Chichester: John Wiley \& sons.

Webler, T. and S. Tuler (2006). Four Perspctives on Public Particpation Process in Environmental Assessment and Decision Making: Combined Results from 10 Case Studies. Policy Studies Journal, 34(4), 699-722.

Wiklund, H. (2005). In Search for Arenas for Democratic Deliberation: A Habermasian Review of Environmental Assessment. Impact Assessment \& Project Appraisal, 23(4), 281-292.

Wiklund, H. and P. Viklund (2006). Public Deliberation in Strategic Environmental Assessment: An Experiment with Citizens' Juries in Energy Planning In: L. Emmelin, ed. Effective Environmental Assessment Tools Dritical Reflections on Concepts and Practice. Karlskrona: Blekinge Institute of Technology, 44-59.

Viklund, P. (1996). Mellan Politik Och Marknad. Traditionell Förvaltingskultur I Jämförelse Med Beställar-Utförarorganisation ed. Sou 1996:169 
Förnyelsemodeller Och Förändringsmodeller I Kommuner Och Landsting 267319.

Wilkins, H. (2003). The Need for Subjectivity in Eia: Discourse as a Tool for Sustainable Development. Environmental Impact Assessment Review, 23(4), 401414.

Wrisberg, N. and U. de Haes, Eds. (2002). Analytical Tools for Environmental Design and Management in a Systems Perspective. The Combined Use of Analytical Tools Dordrecht, Kluwer. 
Table 1. Steps and participants in the energy planning process that was tested in Finspång municipality.

\begin{tabular}{|c|c|c|c|c|}
\hline $\begin{array}{l}\text { Step } \\
\text { no. }\end{array}$ & Task & Description & $\begin{array}{l}\text { Related to decision- } \\
\text { making tool }\end{array}$ & $\begin{array}{l}\text { Responsible } \\
\text { participants }\end{array}$ \\
\hline 0 & Start of process & $\begin{array}{l}\text { The municipal workgroup was } \\
\text { selected, objectives defined, and } \\
\text { time schedule established. }\end{array}$ & --- & $\begin{array}{l}\text { Researchers, civil } \\
\text { servants, } \\
\text { politicians }\end{array}$ \\
\hline \multirow[t]{2}{*}{1} & $\begin{array}{l}\text { Collection of } \\
\text { background } \\
\text { information }\end{array}$ & $\begin{array}{l}\text { Information and analyses of the } \\
\text { current energy system that will } \\
\text { serve as bases for scenarios and } \\
\text { EAs. }\end{array}$ & $\begin{array}{l}\text { - Scenarios } \\
\text { - EA }\end{array}$ & $\begin{array}{l}\text { Researchers, } \\
\text { municipal } \\
\text { workgroup }\end{array}$ \\
\hline & $\begin{array}{l}\text { Appointment of } \\
\text { citizens' panel }\end{array}$ & $\begin{array}{l}\text { A citizens' panel was appointed } \\
\text { after advertisement in newspapers } \\
\text { and networking. }\end{array}$ & $\begin{array}{l}\text { - } \text { Public } \\
\text { participation }\end{array}$ & Civil servants \\
\hline 2 & $\begin{array}{l}\text { Workshop: } \\
\text { "Development } \\
\text { of a visionary } \\
\text { image of the } \\
\text { future" }\end{array}$ & $\begin{array}{l}\text { Workshop with structured } \\
\text { brainstorming about Finspång in } \\
\text { 2040. Selection of most attractive } \\
\text { ideas based on voting. }\end{array}$ & $\begin{array}{l}\text { - Scenarios; } \\
\text { backcasting } \\
\text { - } \text { LCA } \\
\text { - Public } \\
\text { participation }\end{array}$ & $\begin{array}{l}\text { Researchers, } \\
\text { citizens, } \\
\text { municipal } \\
\text { workgroup }\end{array}$ \\
\hline 3 & Visionary image & $\begin{array}{l}\text { The research group composed } \\
\text { desirable future image based on the } \\
\text { most attractive ideas from step } 2 \text {. } \\
\text { The image was revised after step } 4 \text {. }\end{array}$ & $\begin{array}{l}\text { Scenarios; } \\
\text { backcasting }\end{array}$ & Researchers \\
\hline 4 & $\begin{array}{l}\text { Workshop: } \\
\text { "Development } \\
\text { of external } \\
\text { scenarios" }\end{array}$ & $\begin{array}{l}\text { Structured brainstorming on outside } \\
\text { factors that may affect Finspång's } \\
\text { local energy system }\end{array}$ & $\begin{array}{l}\text { - Scenarios; } \\
\text { external scenarios } \\
\text { - Public } \\
\text { participation }\end{array}$ & $\begin{array}{l}\text { Researchers, } \\
\text { citizens, } \\
\text { municipal } \\
\text { workgroup }\end{array}$ \\
\hline 5 & $\begin{array}{l}\text { Workshop: } \\
\text { "Suggestions of } \\
\text { actions and } \\
\text { strategies" }\end{array}$ & $\begin{array}{l}\text { Group discussions on actions and } \\
\text { strategies for a sustainable energy } \\
\text { system as described in the visionary } \\
\text { future image (step 3) for each } \\
\text { external scenario }\end{array}$ & $\begin{array}{l}\text { Scenarios; } \\
\text { external scenarios } \\
\text { and back casting } \\
\text { - Public } \\
\text { participation }\end{array}$ & $\begin{array}{l}\text { Researchers, } \\
\text { citizens, } \\
\text { municipal } \\
\text { workgroup }\end{array}$ \\
\hline 6 & $\begin{array}{l}\text { Selection of } \\
\text { actions and } \\
\text { strategies } \\
\end{array}$ & $\begin{array}{l}\text { Choice of actions that are estimated } \\
\text { possible to act upon }\end{array}$ & & $\begin{array}{l}\text { Municipal } \\
\text { workgroup }\end{array}$ \\
\hline 7 & $\begin{array}{l}\text { Environmental } \\
\text { assessment }\end{array}$ & $\begin{array}{l}\text { Qualitative and quantitative } \\
\text { assessment of the actions and } \\
\text { strategies in relation to the external } \\
\text { scenarios and regional } \\
\text { environmental goals. }\end{array}$ & $\begin{array}{l}\text { - Scenarios; } \\
\text { external scenarios } \\
\text { - EA; LCA and } \\
\text { qualitative } \\
\text { assessment } \\
\end{array}$ & $\begin{array}{l}\text { Researchers, } \\
\text { municipal } \\
\text { workgroup }\end{array}$ \\
\hline 8 & $\begin{array}{l}\text { Valuation and } \\
\text { choice of robust } \\
\text { strategies }\end{array}$ & $\begin{array}{l}\text { Choice of robust actions and } \\
\text { strategies - actions and strategies } \\
\text { that show positive EAs in several } \\
\text { external scenarios. }\end{array}$ & $\begin{array}{l}\text { - Scenarios; } \\
\text { external scenarios } \\
\text { - EA; LCA and } \\
\text { qualitative } \\
\text { assessment } \\
\end{array}$ & $\begin{array}{l}\text { Municipal } \\
\text { workgroup, } \\
\text { researchers }\end{array}$ \\
\hline 9 & $\begin{array}{l}\text { Feedback to the } \\
\text { citizens' panel }\end{array}$ & $\begin{array}{l}\text { Seminar where the citizens' panel is } \\
\text { informed about steps } 6-8 \text {. Group } \\
\text { discussions with panel members } \\
\text { about the results. }\end{array}$ & $\begin{array}{l}\text { - } \text { Public } \\
\text { participation }\end{array}$ & $\begin{array}{l}\text { Municipal } \\
\text { workgroup, } \\
\text { citizens }\end{array}$ \\
\hline 10 & $\begin{array}{l}\text { Development of } \\
\text { implementation } \\
\text { part in energy } \\
\text { plan }\end{array}$ & $\begin{array}{l}\text { Specification and concretisation of } \\
\text { actions and strategies for the energy } \\
\text { plan. }\end{array}$ & --- & $\begin{array}{l}\text { Civil servants } \\
\text { (researchers } \\
\text { advisory) }\end{array}$ \\
\hline
\end{tabular}

